\title{
ENGLISH NAMES OF NEWSPAPERS AND JOURNALS
}

$\begin{array}{ll}\text { Bogoslovskii Vestnik } & \text { The Theological Herald } \\ \text { Den' } & \text { The Day } \\ \text { Golos } & \text { The Voice } \\ \text { Grazhdanin } & \text { The Citizen } \\ \text { Otechestvennye Zapiski } & \text { Notes of the Fatherland } \\ \text { Russkaia Mysl' } & \text { Russian Thought } \\ \text { Russkoe Obozrenie } & \text { The Russian Review } \\ \text { Russkii Invalid } & \text { The Russian Veteran } \\ \text { Russkii Vestnik } & \text { The Russian Herald } \\ \text { Sankt-Peterburgskie Vedomosti } & \text { The St Petersburg News } \\ \text { Sovremennik } & \text { The Contemporary } \\ \text { Svet } & \text { Light } \\ \text { Varshavskii Dnevnik } & \text { The Warsaw Diary } \\ \text { Vostok } & \text { The East } \\ \text { Vremia } & \text { Time } \\ \text { Zaria } & \text { The Dawn }\end{array}$

